\title{
Forsskaolea viridis (Urticaceae) - a new record for the Indian Flora from Kachchh district, Gujarat
}

\author{
Thacker K. ${ }^{1 *}$, Pokar R. ${ }^{2}$, Sumra K. ${ }^{1}$, Nagar P. ${ }^{2}$ \& P. Joshi ${ }^{1}$ \\ ${ }^{1}$ Sahjeevan, 175-Jalaram Society, Bhuj-Kachchh, Gujarat - 370 001, India \\ 2Department of Botany, The Maharaja Sayajirao University of Baroda, Vadodara, Gujarat - 390002 , India \\ *E-mail: khyatithacker5@gmail.com
}

\begin{abstract}
Forsskaolea viridis Ehrenb. ex Webb (Urticaceae), a species native to Africa and the Middle East, is reported here as an addition to the angiosperm flora of India from Gujarat. A detailed description, colour photographs, flowering and fruiting times, details on habitat, plant association and the distribution of the species are provided here.
\end{abstract}

Keywords: Basalt, Forsskaolea, Kachchh, New record, Urticaceae.

\section{Introduction}

Forsskaolea L. (Urticaceae) comprises six species (Ahmed et al., 2019). In India, a single species is documented, F. tenacissima L. from western Punjab (Cooke, 1908). During the floristic exploration of the Dhiodhar hills, an ecologically sensitive area (ESA) cum Medicinal Plant Conservation Area (MPCA) located in Nakhatrana Taluka of Kachchh district in Gujarat, a small population of an annual Urticaceae herb was observed in a rock cleft on a rocky slope by the first author. The voucher specimen was critically examined using the available literature (Hooker, 1888; Cooke, 1908) which suggested it to be a species of Forsskaolea. For verification, identification and confirmation of the species the relevant taxonomic literature was consulted (Hooker, 1849; Friis, 1982; Friis \& Wilmot-Dear, 1988; Friis \& Immelman, 2001; Assaf et al., 2016; Danin \& Fragman-Sapir, 2016+). This confirmed the species as F. viridis Ehrenb. ex Webb. This was further confirmed by comparing the

Received: 01.10.2020; Revised \& Accepted: 22.12.2020

Published Online: 31.03 .2021 voucher specimen with herbarium specimen images at BR, C and E. With no previous record for the Indian subcontinent, we report $F$. viridis as a new addition to the flora of India. A detailed description and colour photographs are provided for easy identification.

\section{Taxonomic treatment}

Forsskaolea viridis Ehrenb. ex Webb in Hook., Niger Fl. 179. 1849. Lectoype (designated by Friis, 1982): Grown in the Paris Bot. Garden, Herb. Desfontaines in Herb. Webb s.n. (FI-W).

Chamaedryfolia viridis Kuntze, Revis. Gen. P1. 2: 625. 1891.

Forsskaolea eenii Rendle, J. Bot., 4: 203. 1917. Fig. 1 Annual herbs, 20-45 cm tall, subulate, hooked hairy all over. Stems herbaceous, 5-angled in crosssection, with distinct ridges; branches ascending, hispid, translucent green, slightly reddish at the base at maturity. Stipules 2, ovate, c. $1 \times 1 \mathrm{~mm}$, acuminate. Leaves simple, alternate; petioles 1-3 $\mathrm{cm}$ long, involute, hairy; lamina ovate to lanceolate, 3-5 × 1.5-2.5 cm, base cuneate, margins serrate, ciliate, apex obtuse, upper surface puberulous, lower surface slightly whitish, woolly, with three prominent veins. Inflorescences bisexual, both male and female flowers aggregated within same involucre of 3-6 bracts; involucres cup shaped, 0.4$0.6 \mathrm{~cm}$, sessile; male flowers in outer whorl and female flowers in the centre of involucre. Bracts obovate, $2.5-4 \times 1-2 \mathrm{~mm}$, acuminate at apex, parallel veined, having soft tufts of white hairs on the margins at the base, hispid. Male flowers 5-12, 

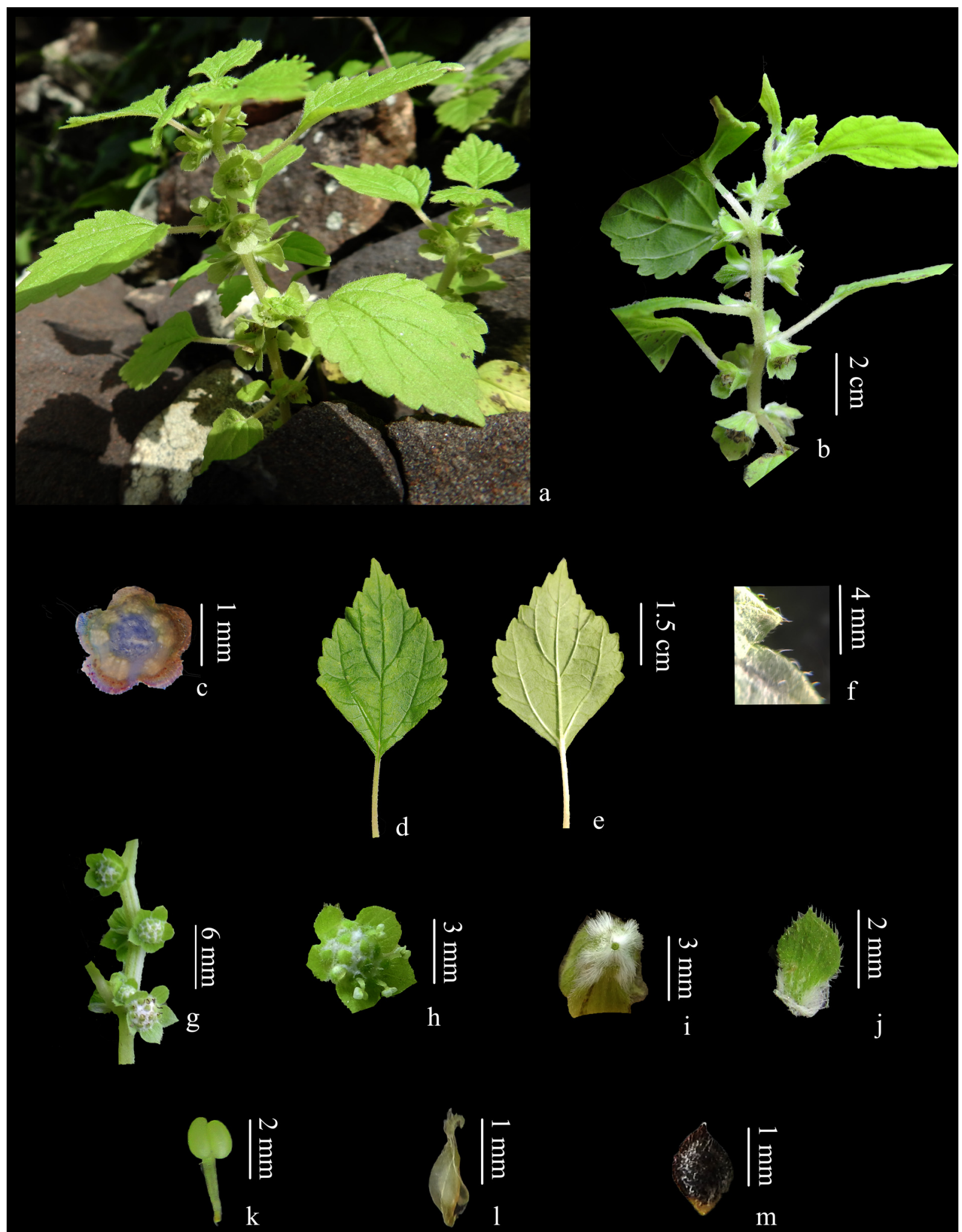

Fig. 1. Forsskaolea viridis Ehrenb. ex Desf.: a. Habitat; b. Habit; c. Transverse section of stem; d. Adaxial side of leaf; e. Abaxial side of leaf; f. Hairs present along leaf margin; g. Flowering twig; h. Inflorescence; i. Back side of involucre showing white indumentum; j. Bract; k. Stamen; I. Female flower; m. Achene (from Khyati Thacker, Ritesh Pokar \& Kazbanu Sumra KRK4012; images by R. Pokar) 
irregular, 1.5-2 $0.5 \mathrm{~mm}$, sessile, inserted in white woolly indumentum. Sepals united, 3-lobed, larger lobe covers inflexed stamen, green, hairy. Stamen single; filament 2.5-3.5 mm long, longer than sepal; anther dorsifixed, dithecous, inflexed, reflexed at the time of dehiscence, whitish green. Female flowers $1-3$, inserted in white woolly hairs; calyx and corolla absent. Gynoecium prolate, pistil single, 2-2.5 mm, straight, sessile; ovary unilocular, placentation basal, ovule single, erect; style filiform; stigma fimbriate. Achenes 2-2.5 mm long, blackish brown.

Flowering \& fruiting: Flowering and fruiting from July to September.

Habitat: Grows in soil between eroded black rocks called deccan trap basalt along with Commelina benghalensis L. (Commelinaceae), Cardiospermum halicacabum L. (Sapindaceae), Cayratia trifolia (L.) Domin (Vitaceae) and Commiphora wightii (Arn.) Bhandari (Burseraceae) at an altitude range from 198 to $352 \mathrm{~m}$. The substrate is predominantly soil and to a lesser extent gravel. The soil type is shallow silty loam. It appears that $F$. viridis has site, habitat and substrate preference as most of the individuals were collected from hills dominated by basalts.

Distribution: Forsskaolea viridis is distributed in Angola, Cape Verde, Djibouti, Egypt, Eritrea, Ethiopia, Kenya, Namibia, Oman, Saudi Arabia, Socotra, Somalia, Sudan, Tanzania, Yemen (Friis \& Wilmot-Dear, 1988) and now in India.

Specimens examined: INDIA, Gujarat, Kachchh district, Dhinodhar hills, N $23^{\circ} 27^{\prime} 15.17^{\prime \prime}$, E $69^{\circ}$ 20' 36.31", 352 m, 27.08.2020, Khyati Thacker, Ritesh Pokar \& Kazbanu Sumra KRK4012, KRK4013, KRK4014 (BARO).

\section{Acknowledgements}

The authors are thankful to Sahjeevan, Prof. NSR Krishanniya, Head, Department of Botany, The
Maharaja Sayajirao University, Baroda, for providing necessary laboratory facilities, Mrs. Jeomol K.K., Department of Botany, University of Calicut, Kerala for confirmation of the species. The first author is grateful to Dr. Kishore Rajput, Associate Professor, The Maharaja Sayajirao University of Baroda, for constant support, Mr. Chetan Misher, ATREE and Mr. Babulal Vaghela, R.R.Lalan College, Bhuj for preparation of figure, and the Adani foundation for financial support.

\section{Literature Cited}

AHMED F.A., EL-MESALLAMY A.M.D. \& T.A.I. ELBASSOSSY 2019. Nutritive value and chemical constituents of Forsskaolea viridis aerial parts. World Journal of Pharmaceutical and Medical Research 5(10): 6-10.

ASSAF H.K., NAFADY A.M. \& M.S. KAMEL 2016. Botanical investigation of the leaf and stem of Forsskaolea tenacissima Linn., family Urticaceae, growing in Egypt. International Journal of Pharmaceutical Science and Research 1(3): 12-19.

COOKE T. 1908. The flora of the Presidency of Bombay: Compositae to Gramineae. Volume 2. Taylor and Francis, London.

DANIN A. \& O. FRAGMAN-SAPIR 2016+. Flora of Israel Online. Available at: http://flora.org.il/en/plants/ (Accessed on 19.09.2020).

FRIIS I. 1982. The typification of Forsskaolea viridis Ehrenb. ex Webb (Urticaceae). Taxon 31(4): 727-729.

FRIIS I. \& C.M. WILMOT-DEAR 1988. A revision of the tribe Forsskaoleae (Urticaceae). Nordic Journal of Botany 8(1): 25-59.

FRIIS I. \& K.L. IMMELMAN 2001. Urticaceae. In GERMISHUIZEN G. (ed.), Flora of southern Africa. Volume 9. National Botanical Institute, Pretoria. pp. 23-26.

HOOKER J.D. 1888. Urticaceae. In: HOOKER J.D. (ed.), The flora of British India, Volume 5. L. Reeve \& Co., London, pp. 477-594.

HOOKER W.J. 1849. Niger flora: or, an enumeration of the plants of western Tropical Africa. Hippolyte Bailliere Publisher, London. 